\title{
Desinfeksi Novel Corona Virus di Dalam Air Minum PDAM dan Air Limbah Untuk Fase Normal Baru
}

\author{
Gede H. Cahyana \\ Universitas Kebangsaan Republik Indonesia, Bandung \\ Koresponden email: ghcahyana@gmail.com
}

Diterima: 8 Juli 2020

Disetujui: 1 Agustus 2020

\begin{abstract}
The purpose of this literature review is to review the effectiveness of chlorination in eradicating viruses (and bacteria) in drinking water and wastewater so that people can get scientific information on the practice of eradicating the new Corona virus. The research method was carried out by reviewing scientific articles obtained from the search engine scholar.google.com, the National Library website and textbooks. Chlorine is able to deactivate the virus on objects that are splashed by the patient's saliva. Giving chlorine doses of $0.2-40 \mathrm{mg} / 1$ and remaining free chlorine $0.2-0.5 \mathrm{mg} / 1$, chlorination is effective in eradicating viruses and bacteria in drinking water. When the bacteria die, the virus dies or is inactive. The new Corona virus blanket can also be destroyed by chlorine. Researchers have also found genetic traces of the new Corona virus in wastewater. The genetic traces of the new Corona virus found in wastewater could be a latent danger for a new outbreak in the post-pandemic or new normal period. PDAM water that contains chlorine becomes important during the new normal period so it must be provided in public and social facilities.
\end{abstract}

Keywords: COVID-19, chlorination, disinfection, drinking water, wastewater

\begin{abstract}
Abstrak
Literatur review ini bertujuan mengulas keefektifan klorinasi dalam membasmi virus (dan bakteri) di air minum dan air limbah agar masyarakat memperoleh informasi ilmiah dalam praktek pembasmian virus Korona baru. Metode penelitian dilakukan dengan mereview artikel-artikel ilmiah yang diperoleh dari mesin pencari scholar.google.com, situs Perpustakaan Nasional dan buku teks. Klor mampu menonaktifkan virus pada benda yang terkena percikan liur pasien. Pemberian klor dosis $0,2-40 \mathrm{mg} / \mathrm{l}$ dan sisa klor bebas $0,2-0,5 \mathrm{mg} / \mathrm{l}$, klorinasi efektif membasmi virus dan bakteri dalam air minum. Apabila bakterinya mati, virus ikut mati atau nonaktif. Selimut virus Korona baru juga bisa dihancurkan oleh klor. Para peneliti juga sudah menemukan jejak genetis virus Korona baru di air limbah. Jejak genetis virus Korona baru yang ditemukan di air limbah bisa menjadi bahaya laten wabah virus baru pada masa pasca pandemi atau new normal. Air PDAM yang mengandung klor menjadi penting pada masa normal baru sehingga harus disediakan di fasilitas umum dan sosial.
\end{abstract}

Kata Kunci: air minum, air limbah, COVID-19, desinfeksi, klorinasi

\section{Pendahuluan}

World Health Organization (WHO) menyatakan bahwa virus Novel Coronavirus pertama kali muncul di Kota Wuhan, Provinsi Hubei, China pada Desember 2019. Tipe virus Korona baru ini termasuk subfamili Coronavirinae dalam famili Coronaviridae dan ordo Nidovirales ([1]. Virus baru yang disebut SARS-CoV-2 ini masih satu famili dengan Severe Acute Respiratory Syndrome Coronavirus (SARS-CoV atau SARS) dan Middle East Respiratory Syndrome Coronavirus (MERS-CoV atau MERS). SARS-CoV-2 tersebut diduga berasal dari anjing yang biasa dimakan oleh penduduk Wuhan. Kejadian tersebut sama dengan epidemi SARS tahun 2003 dengan lebih dari 8.000 kasus di seluruh dunia dan mortality rate 10\% [2]. Pada kasus SARS 2003 tersebut dinyatakan bahwa musang dan kelelawar sebagai sumber dan reservoir virus [3][4][5].

Ketiga jenis virus tersebut memiliki sifat fisika dan biokimia yang sama, semuanya virus berselimut (enveloped) dengan genom RNA utas-tunggal (single-stranded). [6] menyatakan bahwa bentuk fisik virus tersebut juga sama, yaitu memiliki mahkota (Latin: corona, Inggris: crown) dengan bentuk bola berdiameter 60-220 $\mathrm{nm}$. Virus tersebut sering menginfeksi burung, mamalia dan manusia dengan transmisi lewat aerosol atau jalur fekal-oral. Sebarannya semakin cepat dan luas lewat muncratan liur (droplets) pasien. Namun bukti muncratan liur ini dulu diragukan oleh [6], "there is no direct 
evidence to support this. Sebaliknya WHO berpendapat lain sejak epidemi SARS (2003), MERS (2012) hingga pandemi COVID-19 (CO: Corona, VI: virus, D: disease, 19 adalah tahun mulai wabah 2019). WHO menyatakan bahwa muncratan liur pasien makin meluaskan sebaran virus Korona. Kontak fisik antara dokter, paramedis, dan pasien juga interaksi fisik (social - physical distancing) masyarakat dan pasien mengakibatkan jumlah orang sakit tumbuh secara eksponensial [7][8].

Di Indonesia wabah ini secara resmi diumumkan oleh Presiden Joko Widodo pada 2 Maret 2020. Saat itu Presiden menyatakan bahwa ada dua orang WNI terinfeksi virus Korona baru. Setelah pengumuman tersebut penduduk di Jakarta, Bandung dan Surabaya menjadi panik dan memborong kebutuhan pokok harian. Sembilan kebutuhan pokok, masker, dan sanitangan (hand sanitizer) menjadi langka dan mahal harganya akibat panic buying atau rush buying (beli-rusuh). Kemudian pada 11 Maret 2020 WHO menetapkan wabah ini sebagai pandemi, yaitu berjangkit serempak di mana-mana, meliputi geografi yang luas di seluruh dunia. Sampai 7 Juli 2020 sudah terjadi di 216 negara. Jumlah yang sakit hingga 7 Juli 2020 lebih dari 11.764 .000 orang, yang meninggal lebih dari 541.000 orang dan sembuh 6.753 .000 orang. Di Indonesia terjadi di semua provinsi, pasien berjumlah lebih dari 66.266 orang, meninggal 3.309 orang, sembuh lebih dari 30.785 orang [7][8].

\section{Metode Penelitian}

Artikel ini membahas kemampuan disinfektan senyawa klor seperti khlorin, kaporit, sodium hipoklorit dalam membasmi bakteri dan virus. Pembahasan difokuskan pada pemanfaatan senyawa klor untuk desinfeksi di dalam air minum yang diolah oleh Perusahaan Daerah Air Minum (PDAM), perusahaan daerah yang ada di hampir semua kabupaten-kota di Indonesia. Artikel ini juga mengulas desinfeksi di dalam pengolahan air limbah, yaitu Instalasi Pengolahan Air Limbah (IPAL) yang dikelola oleh PDAM. IPAL yang dianalisis adalah IPAL Bojongsoang yang dikelola oleh PDAM Kota Bandung.

Semua artikel yang dijadikan rujukan diperoleh dari internet dengan fokus pada wabah yang disebabkan oleh virus Korona seperti wabah SARS dan MERS, termasuk wabah Covid-19 yang dirilis di portal berita internasional dan website WHO antara bulan Maret dan Juni 2020. Artikel diperoleh dengan memanfaatkan scholar.Google.com, fasilitas di website Perpustakaan Nasional, dan website berita dan rubrik sainstek portal berita internasional. Adapun sumber ilmiah lainnya adalah buku-buku teks di bidang Teknik Penyehatan (Sanitary Engineering) dan Teknik Lingkungan (Environmental Engineering). Buku teks tersebut menjadi rujukan utama dalam perkuliahan dan penulisan artikel ilmiah.

Artikel dan buku teks dikelompokkan ke dalam materi yang membahas pemanfaatan klor sebagai disinfektan untuk membasmi bakteri dan virus Korona SARS dan MERS dan hipotesis untuk novel Corona virus penyebab COVID-19. Uraian ditulis dalam bentuk narasi deskriptif yang dipisahkan menjadi beberapa sub bab sehingga dapat memberikan alur penjelasan yang runtut, mulai dari pengenalan zat kimia desinfektan, proses klorinasi di dalam air minum, klorinasi di dalam air limbah dan persistensi virus korona di dalam air limbah.

\section{Hasil Dan Pembahasan}

\subsection{Upaya Preventif dan Kuratif}

Karakteristik virus Korona baru sedang diteliti di sejumlah negara dan dikaji dalam aspek virologi lingkungan (environmental virology), yaitu kajian yang fokus pada transmisi virus ke dalam air minum, air limbah, tanah dan udara. Kajian virologi lingkungan ini berawal dari kasus infeksi virus yang menimbulkan wabah penyakit hepatitis di New Delhi, India pada Desember 1955 hingga Januari 1956 [9]. Virus hepatitis tersebut menginfeksi 30.000 orang karena air Sungai Jumna (Yamuna) sebagai sumber air minum penduduk terkontaminasi oleh air limbah domestik. Air limbah domestik ini mengandung lebih dari 100 spesies virus, baik yang berbahaya maupun yang tidak berbahaya [10].

Potensi bahaya virus Korona baru terjadi dalam kontak sosial dan fisik di masyarakat. Percikan atau muncratan (droplets) liur seseorang ketika batuk atau bersin, juga cairan hidung, telinga, ludah yang menempel di benda-benda pada fasilitas umum seperti tombol lift, pagar tangga dan eskalator, lavatory, faucet, urinal, water closet bisa menjadi sumber virus. Semua permukaan alat plambing (plumbing fixtures) di ruang toilet bandara, stasiun kereta api, terminal bis juga bisa menjadi sumber virus. Bahkan bagian dalam pipa air yang berupa endapan kimia dan biofilm juga mengandung virus [11]. Karena virus Korona baru mudah menyebar maka pemerintah setiap negara berupaya membasmi dengan berbagai cara. Pemerintah pusat dan daerah di Indonesia mengeluarkan peraturan dan mengajak ulama, tokoh agama untuk menghimbau masyarakat agar bekerja, belajar dan beribadah di rumah. 
Salah satu himbauan yang disampaikan pemerintah untuk mengurangi risiko penularan COVID-19 adalah dengan memperkuat daya tahan tubuh, kekebalan atau imunitas. Upaya pertama ini adalah upaya preventif atau pencegahan. Makin sehat seseorang akan makin sulit diinfeksi oleh virus. Agar tubuh sehat maka seseorang harus cukup makan makanan bergizi, asupan karbohidrat, protein, lemak, vitamin, mineral, dan air bersih. Selain makanan pokok, beberapa makanan yang disarankan adalah madu, sayur, dan buah-buahan bervitamin $\mathrm{C}$ seperti tomat, jambu biji, jeruk lemon atau nipis. Juga mengonsumsi rempah, rimpang seperti jahe, kunyit, dan kencur. Ditambah dengan olah raga rutin seperti jalan kaki, senam atau gerak badan lainnya.

Upaya kedua adalah tindakan kuratif untuk orang yang positif Korona yaitu pengobatan dan isolasi. Upaya kuratif ini dilaksanakan oleh dokter, paramedis di rumah sakit khususnya rumah sakit yang memiliki ruang isolasi. Pasien COVID-19 diisolasi dan dirawat di ruang khusus. Virus Korona diupayakan mati di dalam ruang perawatan pasien sehingga sebaran virus bisa dihentikan. Sementara itu imunitas pasien terus diperkuat dengan obat, asupan suplemen vitamin, makanan bergizi sehingga pasien bisa bertahan dan melewati masa kritisnya sampai sehat kembali. Dalam proses pengobatan ini hanya dokter dan perawat yang boleh kontak dengan pasien dan harus mengikuti standar protokol penyakit menular, yaitu mengenakan alat pelindung diri (APD) seperti hazmat, sarung tangan, dan masker N95 [12].

Namun demikian, sebaran COVID-19 ke seluruh dunia menandakan bahwa tidak mudah menghentikan virus ini. Faktor ekonomi dan hubungan sosial satu orang dengan orang lain menjadi salah satu sebab. Satu bulan pertama setelah diumumkan oleh pemerintah Republik Indonesia nyaris tidak ada social-physical distancing yang ditaati oleh masyarakat. Penduduk tidak menjaga jarak dalam komunikasi langsung dan berperilaku seolah-olah tidak ada wabah. Sebaran virus ini makin luas lantaran ada orang yang tampak sehat tetapi di dalam tubuhnya berisi virus. Orang yang harus diwaspadai adalah yang positif COVID-19 dengan cara menghindar dari muncratan liur dan cairan hidung yang melekat di bendabenda sekitar. The New England Journal of Medicine edisi 17 Maret 2020 merilis surat dari Van Doremalen, Bushmaker dan Morris. Surat tersebut menyatakan bahwa Korona bisa bertahan tiga jam di dalam aerosol, empat jam di permukaan tembaga, 24 jam di permukaan karton dan bertahan tiga hari di permukaan plastik dan logam stainless [13].

Upaya preventif dan kuratif ternyata belum cukup untuk melawan Korona. Penguatan kekebalan tubuh seseorang perlu ditambah dengan upaya ketiga yaitu tindakan mekanis. Tindakan mekanis ini dilakukan dengan cara memanfaatkan biosida zat kimia. Zat kimia yang bisa digunakan ialah fenol, logam berat, hidrogen peroksida, asam, alkali (basa), dyes, sabun, deterjen sintetis [14]. Sabun dan deterjen mudah diperoleh dan banyak digunakan masyarakat untuk membasmi bakteri dan virus. Sabun padat yang dibuat dari alkali natrium hidroksida dan sabun cair yang dibuat dari alkali kalium hidroksida efektif untuk membunuh bakteri dan virus. Kedua wujud sabun tersebut ada yang dilengkapi dengan antiseptik seperti senyawa triclosan atau triclocarban meskipun kedua senyawa ini masih diperdebatkan bahaya atau risikonya terhadap manusia. Bisa juga menggunakan senyawa lain, yaitu alkohol $70 \%$ atau produk komersial yang berisi alkohol seperti sanitangan (hand sanitizer). Ada satu lagi yang bisa digunakan, yaitu air olahan PDAM yang mengandung klor.

\subsection{Instalasi Pengolahan Air Minum}

PDAM mengolah air baku dari sungai, waduk, danau, atau muara (air payau) menggunakan Instalasi Pengolahan Air Minum (IPAM) yang terdiri atas unit proses dan unit operasi prasedimentasi, aerasi, kogulasi, flokulasi, sedimentasi, filtrasi, dan desinfeksi [15]. Tentu masih ada lagi unit proses dan unit operasi lainnya, bergantung pada kualitas air baku yang diolah dan kualitas air minum yang diinginkan. Adapun unit untuk membasmi bakteri dan virus disebut unit proses desinfeksi atau lebih khusus lagi disebut klorinasi apabila zat kimia yang digunakan adalah klor.

Menurut sejarahnya, proses klorinasi menggunakan gas klor pertama kali dilaksanakan pada tahun 1887 di Amerika Serikat sedangkan klor cair digunakan sejak 1914. Di Jersey City, New Jersey, USA senyawa klor ini digunakan sebagai disinfektan di dalam penyediaan air minum pada tahun 1908 oleh George Johnson dan John Leal [16]. Adapun di London pertama kali digunakan pada tahun 1854 tetapi berupa kaporit atau chlorinated lime [17]. Senyawa klor ditemukan oleh ahli kimia dari Swedia bernama Scheele (1742-1786). Dalam sistem periodik, klor termasuk golongan halogen (VIIA) yang memiliki 7 elektron di kulit terluar. Senyawa halogen lain yang bisa digunakan untuk desinfeksi adalah bromine dan iodine [14]. Tujuh elektron di kulit terluar sangat stabil sehingga cenderung sebagai oksidator pada setiap reaksi kimia. Maka klor yang dilarutkan di dalam air PDAM akan mengoksidasi atau membunuh mikroba yang ada di dalam air tersebut.

Semua PDAM di Indonesia menggunakan klor dalam proses desinfeksi airnya. Bisa dikatakan, 
sejarah desinfeksi identik dengan sejarah klorinasi. Jenis senyawa klor yang biasa digunakan untuk desinfeksi di PDAM adalah kaporit (kalsium hipoklorit, $\mathrm{Ca}(\mathrm{OCl}) 2)$. Sebutan lain kaporit adalah bleaching powder atau chlorinated lime. Desinfektan lainnya yang juga biasa digunakan adalah natrium hipoklorit ( $\mathrm{NaOCl}$ ), klor (chlorine, $\mathrm{Cl} 2$ ), chloramines [18]. Klor diinjeksikan ke dalam air bersih di reservoir dengan kisaran waktu kontak ( $\mathrm{t}$, time) antara 15-30 menit. Dosis klor yang biasa digunakan adalah $0,2-40 \mathrm{mg} / \mathrm{l}$. Keuntungan menggunakan klor untuk desinfeksi adalah adanya sisa klor bebas antara $0,2-0,5 \mathrm{mg} / 1$ [19]. Sisa klor bebas ini dibutuhkan apabila di pipa distribusi yang ditanam dalam tanah terjadi rekontaminasi bakteri dan virus akibat kebocoran pipa. Sisa klor inilah yang diharapkan membasmi bakteri dan virus di dalam air yang masuk melalui pipa bocor.

Klor bisa dijadikan desinfektan karena memenuhi karakteristik sebagai biosida yaitu: (1) toksik bagi mikroba pada konsentrasi yang tidak berbahaya bagi manusia dan hewan; (2) cepat bereaksi membunuh virus dan bakteri dengan waktu kontak yang singkat; (3) tahan lama sehingga mampu menanggulangi infeksi akibat rekontaminasi di zone distribusi; (4) murah dan mudah diperoleh; (5) mudah dianalisis di laboratorium; dan (6) mudah menentukan dosisnya [20]. Adapun WHO memberikan rekomendasi klorinasi yang mengacu pada hasil kali antara konsentrasi $\mathrm{C}$ dan waktu kontak $t$ sebesar 15 mg.menit/liter. Rumusan hasil kali konsentrasi klor dan waktu kontak ini diberikan oleh hukum Watson [21]. Angka ini dapat dilihat pada Gambar 1, yaitu 0,5 mg/l sisa klor bebas dengan waktu kontak 30 menit. C adalah konsentrasi klor dan $t$ adalah waktu kontak [22]. Keefektifan (effectiveness) klorinasi juga bergantung pada bentuk ruang reservoir. Bentuk berkelok dengan sekat (baffle) adalah bentuk terbaik karena dapat menghasilkan jenis aliran plug flow [23]. Oleh sebab itu, reservoir air bersih PDAM hendaklah didesain berkelak-kelok mulai dari zone inlet (bagian air masuk) hingga di zone outlet (bagian air keluar).

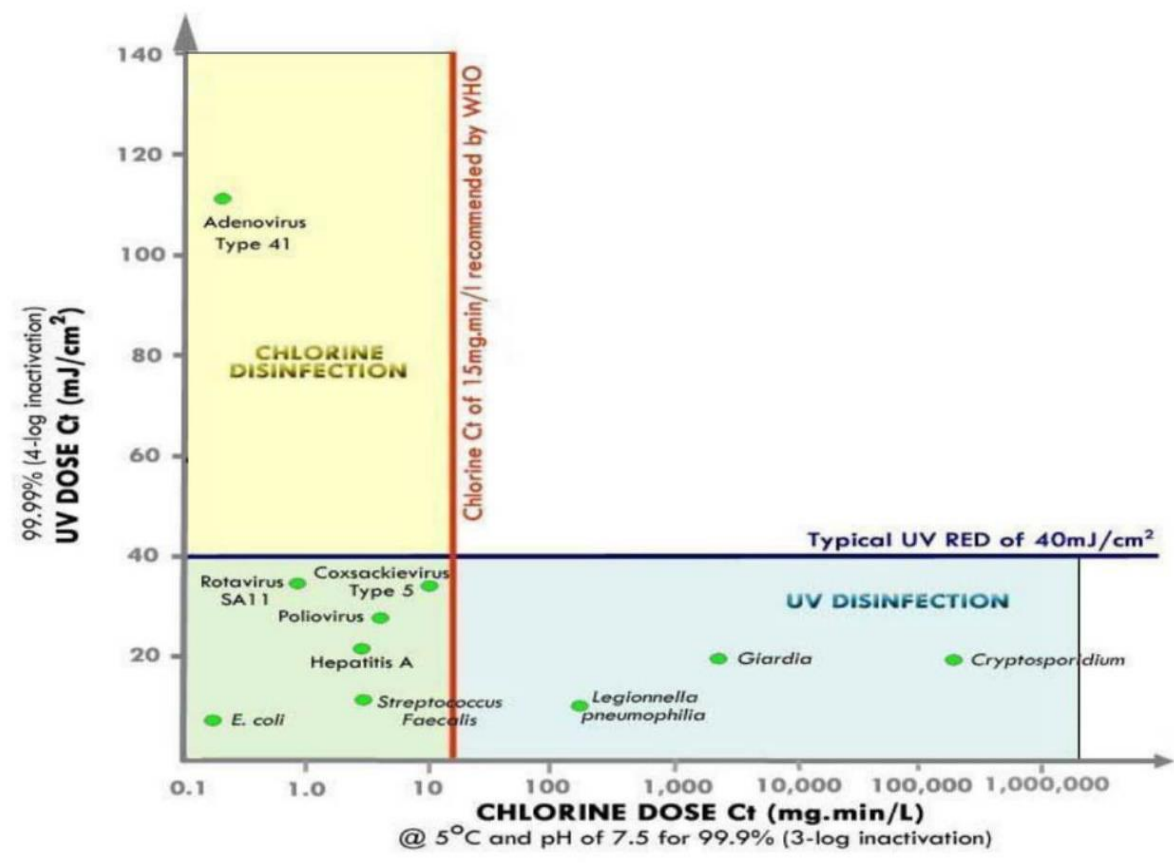

Gambar 1. Kemampuan Klor dan sinar UV dalam membasmi virus [22]

Rekomendasi [22] tersebut dikutip lagi oleh EHS Water pada 5 Maret 2020 dalam sebuah catatan (note) untuk pembasmian virus Korona baru. Isi catatan tersebut tentang kemampuan klor sebagai oksidator yang mampu merusak DNA bakteri dan RNA virus. Bakteri biasanya dijadikan inang oleh virus sehingga virus bisa hidup dan bertahan. Apabila bakterinya mati maka virusnya juga mati. Mengutip [22], rilis EHS Water tersebut menyatakan bahwa Coxsackievirus, Poliovirus dan Rotavirus adalah virus tidak berselimut (non-enveloped virus) yang bisa dibasmi pada nilai Ct kurang dari 15 mg.menit/liter (Gambar 1). Karena Korona adalah virus berselimut (enveloped virus) maka bisa dibasmi dengan nilai $\mathrm{Ct}$ yang lebih rendah. Prosedur untuk memperoleh parameter $\mathrm{Ct}$ ini sangat kompleks atau rumit karena bergantung pada sistem pengolahan air, tipe dan jumlah titik aplikasinya, dan konsentrasi sisa disinfektan [24]. Agar klorinasi makin efektif, WHO juga menetapkan nilai pH air 
antara 6,5-8,5 dan yang paling efektif adalah $\mathrm{pH} 8,0$ [12]. Keefektifan klorinasi juga dipengaruhi oleh waktu kontak teoretis (theoretical contact time) dan waktu kontak ini bergantung pada volume tangki dan debit air yang diolah [25].

Volume atau debit air yang diolah oleh PDAM sangat besar karena melayani ratusan ribu pelanggan. Sebagai contoh, kapasitas pengolahan PDAM Kota Bandung di satu IPAM saja yaitu di IPAM Badaksinga sekitar 1.800 liter per detik. Apabila kebutuhan air setiap orang perhari adalah 150 liter dan asumsi kehilangan air 20\% maka air yang diolah di IPAM Badaksinga tersebut bisa untuk melayani 829.440 orang. Untuk kapasitas sebesar itu maka yang paling layak digunakan adalah gas klor (chlorine). PDAM juga disarankan menambah dosis klor selama wabah COVID-19 dan masa normal baru (new normal) agar air masih memiliki sisa klor di lokasi terjauh dari instalasi. Sisa klor inilah yang akan membasmi bakteri dan virus pada waktu seseorang mencuci tangan.

Dalam upaya melawan virus Korona baru, PDAM Kota Bandung sudah memanfaatkan air produksinya untuk membersihkan fasilitas umum. Senyawa yang digunakan sebagai desinfektan adalah natrium atau sodium hipoklorit $0,5 \%(\mathrm{NaOCl})$. Enam truk tangki dengan volume total 30.000 liter menyemprotkan air berkonsentrasi $10 \mathrm{mg} / \mathrm{l} \mathrm{klor} \mathrm{ke} \mathrm{fasilitas} \mathrm{umum} \mathrm{seperti} \mathrm{halte} \mathrm{bis,} \mathrm{terminal} \mathrm{bis,} \mathrm{stasiun}$ kereta api. Penyemprotan dilaksanakan setiap malam selama tujuh malam pada pekan keempat Maret 2020. Adapun untuk kapasitas kecil, misalnya untuk kebutuhan rumah tangga, masjid, gereja, vihara, pura, kantor bisa dengan memanfaatkan kaporit tablet yang dijual bebas di toko kimia. Satu kaporit tablet bisa untuk 500-1.000 liter air. Dilarang menarik napas dalam-dalam di atas tangki air karena klor bersifat korosif, bisa menimbulkan iritasi pada paru-paru. Sebaiknya gunakan masker kalau ingin melihat apakah kaporit tablet masih ada atau sudah habis.

Dapat disimpulkan bahwa selain upaya preventif dan kuratif, tindakan mekanis untuk pencegahan sebaran virus Korona baru bisa dilaksanakan dengan air yang mengandung senyawa klor yang diproduksi PDAM di seluruh Indonesia. Untuk skala kecil bisa dengan air sumur yang diolah dengan kaporit tablet sehingga memiliki sisa klor bebas (free chlorine residual) [26].

\subsection{Instalasi Pengolahan Air limbah}

Jejak genetis novel Coronavirus sudah ditemukan di dalam air limbah dimana pernyataan ini dirilis oleh peneliti di RIVM National Institute for Public Health and the Environment di laman situsnya pada 19 Maret 2020. Jejak virus dalam air limbah domestik (sewage) tersebut diperoleh dari sampel di instalasi pengolahan air limbah pelabuhan udara Schiphol, Amsterdam dan di IPAL Kaatsheuvel, Belanda. Peneliti RIVM memberikan indikasi bahwa jejak itu adalah novel Coronavirus. Memang tidak semua sampel yang dianalisis menghasilkan data positif jejak genetis virus Korona baru. Tetapi beberapa sampel yang positif itu memberikan kesimpulan sementara bahwa air limbah berpotensi menjadi sumber biakan virus Korona. Jejak genetis virus tersebut berasal dari tinja (feses) pasien atau orang yang sehat tetapi di dalam tubuhnya ada virus Korona baru. Kondisi ini akan berpotensi menjadi bahaya laten wabah COVID-19.

Temuan jejak genetis novel Coronavirus di IPAL bandara Schiphol dan di IPAL Kaatsheuvel adalah pengulangan temuan jejak genetis virus SARS (severe acute respiratory syndrome) di dalam air limbah beberapa tahun lalu. Dengan uji PCR (polymerase-chain reaction) asam nukleat dari SARS-CoV tersebut ditemukan di dalam air limbah sebelum proses desinfeksi di 309th Hospital of Chinese People's Liberation Army dan di Xiao Tang Shan Hospital Beijing. Setelah proses desinfeksi ternyata RNA SARS$\mathrm{CoV}$ masih dapat dideteksi dari beberapa sampel air limbah rumah sakit 309th Chinese People's Liberation Army tetapi tidak ditemukan di dalam sampel air limbah dari Xiao Tang San Hospital. Penelitian itu menyatakan bahwa virus mampu bertahan selama 14 hari di dalam air limbah pada temperatur 4 derajat Celcius, 2 hari pada 20 derajat Celcius dan RNA virus dapat dideteksi selama 8 hari meskipun virus sudah dinonaktifkan. Penelitian ini sekali lagi menunjukkan bahwa RNA SARS-CoV dapat dideteksi kehadirannya di dalam air limbah rumah sakit sebelum dan sesudah proses desinfeksi [27].

Selama epidemi SARS tahun 2003, merujuk pada laporan WHO tanggal 5 Juli 2003, terjadi 8.439 kasus di 32 negara dan 812 orang di antaranya meninggal. Pada waktu itu mekanisme transmisi SARS$\mathrm{CoV}$ terbatas pada interaksi sosial antara orang-orang yang dekat dengan pasien. Penelitian tersebut juga menyatakan bahwa ada jejak genetis RNA Corona virus di dalam tinja (feses) yang air limbahnya berasal dari pasien di Amoy Gardens Housing Estate di Hong Kong [27]. Kasus tersebut terjadi karena ada pipa plumbing air limbahnya yang rusak, yaitu pipa berbentuk U atau di Indonesia disebut pipa "leher angsa" yang fungsinya sebagai trap (perangkap) yang berisi air (water seal). Kerusakan pipa tersebut menyebabkan virus dari percikan atau muncratan liur pasien dapat masuk ke sistem plumbing yang kemudian menginfeksi orang lain di kamar mandi yang lain. Akibatnya di kompleks gedung Amoy Gardens tersebut terjadi 300 kasus dan 42 orang meninggal [28]. 
Epidemi SARS pada 2003 tersebut juga memiliki kaitan kuat dengan sistem air limbah apartemen yang buruk di Hong Kong dengan populasi 300 orang seperti dinyatakan oleh [29]. Air limbah domestik dengan feses dari pasien menjadi sumber sebaran virus SARS-CoV. Virus ini mampu replikasi di saluran pencernaan pasien sehingga terdeteksi dalam kasus diare sebesar 8 sampai 73\% [30]. Penelitian [30] juga menyatakan bahwa masih ada virus di saluran pencernaan pasien SARS yang sudah sembuh. Virus ini terdeteksi di feses pasien SARS yang diambil sampelnya hingga tiga pekan setelah terinfeksi [31]. Begitu pula [31] meneliti perihal ketahanan virus Korona di dalam air bersih dan air limbah domestik.

Setiap kota besar di Indonesia memiliki fasilitas pengolahan air limbah. Jenis unit operasi dan unit proses yang digunakan bisa berbeda-beda. Ada activated sludge dan modifikasinya, ada trickling filter, ada oxidation pond. Semuanya adalah pengolahan sekunder (secondary treatment) secara bioproses. Ada juga unit pengolahan yang khusus menerima air limbah dari septic tank yang disebut Instalasi Pengolahan Lumpur Tinja (IPLT) dan diolah secara aerob dengan menggunakan aerator mekanis (mechanical surface aerator). Semua bioproses tersebut memiliki kelebihan dan kekurangan. Instalasi pengolahan air limbah yang akan dianalisis adalah instalasi milik PDAM Kota Bandung, yaitu oxidation pond.

\subsection{Oxidation Pond}

Bojongsoang adalah nama desa di tepi Sungai Citarum, Kabupaten Bandung. Di desa ini ada IPAL domestik jenis oxidation pond terluas ( 85 hektar) di ASEAN. Merujuk pada nomenklatur, ada dua nama lain kolam oksidasi (oxidation pond), yaitu kolam stabilisasi (stabilization pond) dan lagoon. Klasifikasi kolam oksidasi berdasarkan metabolisme terdiri atas kolam anaerobik, kolam fakultatif, kolam aerobik (maturasi), dan laguna aerasi atau aerated lagoon [32]. Jenis metabolisme yang terjadi di dalam kolamkolam tersebut bergantung pada aktivitas biologi yang dominan dan reaksi biokimianya serta dipengaruhi oleh kecepatan pembebanan organik atau organic loading rate yang diterapkan di dalam kolam [19].

Kolam pertama yang menerima air limbah adalah kolam anaerobik. Di kolam ini terjadi proses pengolahan air limbah tanpa oksigen. Ada dua fenomena di kolam anaerobik, yaitu (1) fenomena fisika berupa sedimentasi zat padat di dalam air limbah menjadi lumpur (sludge); (2) fenomena biokimia, yaitu degradasi zat organik oleh bakteri anaerob [19]. Proses biokimia di kolam dengan kedalaman 2,5-5 m ini berlangsung dua tahap. Pada tahap pertama zat organik kompleks (makro-molekul) diubah menjadi mikromolekul dengan proses hidrolisis, asidogenesis dan asetogenesis. Pada tahap ini belum terjadi reduksi BOD dan COD secara signifikan. Setelah archae metanogenik mengubah asam asetat dan asamasam rantai pendek lainnya menjadi gas metana dan karbondioksida maka reduksi BOD dan COD menjadi besar. Perubahan polutan organik yang mayoritas adalah feses menjadi gas $\mathrm{CH}_{4}$ dan $\mathrm{CO}_{2}$ adalah indikator efisiensi pengolahan anaerobik [33].

Ilustrasi dan penjelasan tentang transportasi feses dan virus di dalam air limbah dapat dilihat pada Gambar 2. Titik awal feses pasien COVID-19 yang berisi virus Korona bermula dari water closet (WC). Feses bersama air kemudian mengalir di dalam pipa riul (riool, sewer) menuju kolam anaerobik. Seperti namanya, air limbah di dalam kolam anaerobik hanya diolah oleh bakteri strict anaerobes seperti Clostridium butyricum, Clostridium pasteurianum, Butyrivibrio fibrisolvens [34]. Archae, istilah ini lebih tepat daripada bakteri, yang ikut mengolah air limbah adalah metanothrix atau methanosaeta dan metanosarcina [33]. Merujuk [35], mikroba anaerob ini tidak mampu mereduksi persistensi virus dibandingkan dengan mikroba aerob yang ada di tanah. Ref [36] juga menyatakan bahwa mikroba mampu mereduksi persistensi virus pada temperatur tinggi tetapi kurang mampu pada temperatur rendah. Pada temperatur satu derajat Celcius dinyatakan bahwa poliovirus, sebagai salah satu jenis virus, mampu stabil selama 70 hari. Apabila mikroba anaerob tersebut tidak mampu dinonaktifkan oleh virus maka virus akan menjadikan mikroba sebagai inang untuk replikasi.

Proses di kolam anaerobik tersebut berlangsung selama 24 jam sehari, yaitu selama air limbah dari penduduk mengalir ke dalam IPAL. Pada Gambar 2 juga dijelaskan tentang air limbah yang langsung masuk ke sungai tanpa diolah. Ada penduduk yang langsung membuang air limbah WC-nya ke selokan atau sungai. Artinya, pada faktanya di masyarakat, virus yang ada di dalam feses akan masuk ke lingkungan melalui air limbah yang diolah dan air limbah yang tidak diolah maka tidak mungkin ada efluen air limbah yang bebas virus (unable to provide virus-free wastewater effluent). Konsentrasi virus di dalam air limbah mentah antara 5,000-100,000 pfu/L [37] dan virus tersebut mampu direduksi oleh unit pengolahan. Persentase reduksinya bergantung pada unit bioproses yang diterapkan tetapi tidak ada unit bioproses yang memiliki efisiensi $100 \%$. Oleh karena itu, konsentrasi virus antara 50-100 pfu/L ditemukan di effluent IPAL yang menuju ke sungai [37]. Ada juga sejumlah peneliti yang menyatakan bahwa konsentrasi virus di dalam feses manusia adalah rendah dan bisa cepat dinonaktifkan di dalam air. Tetapi beberapa bukti menunjukkan bahwa asumsi ini tidak selalu benar [38]. 


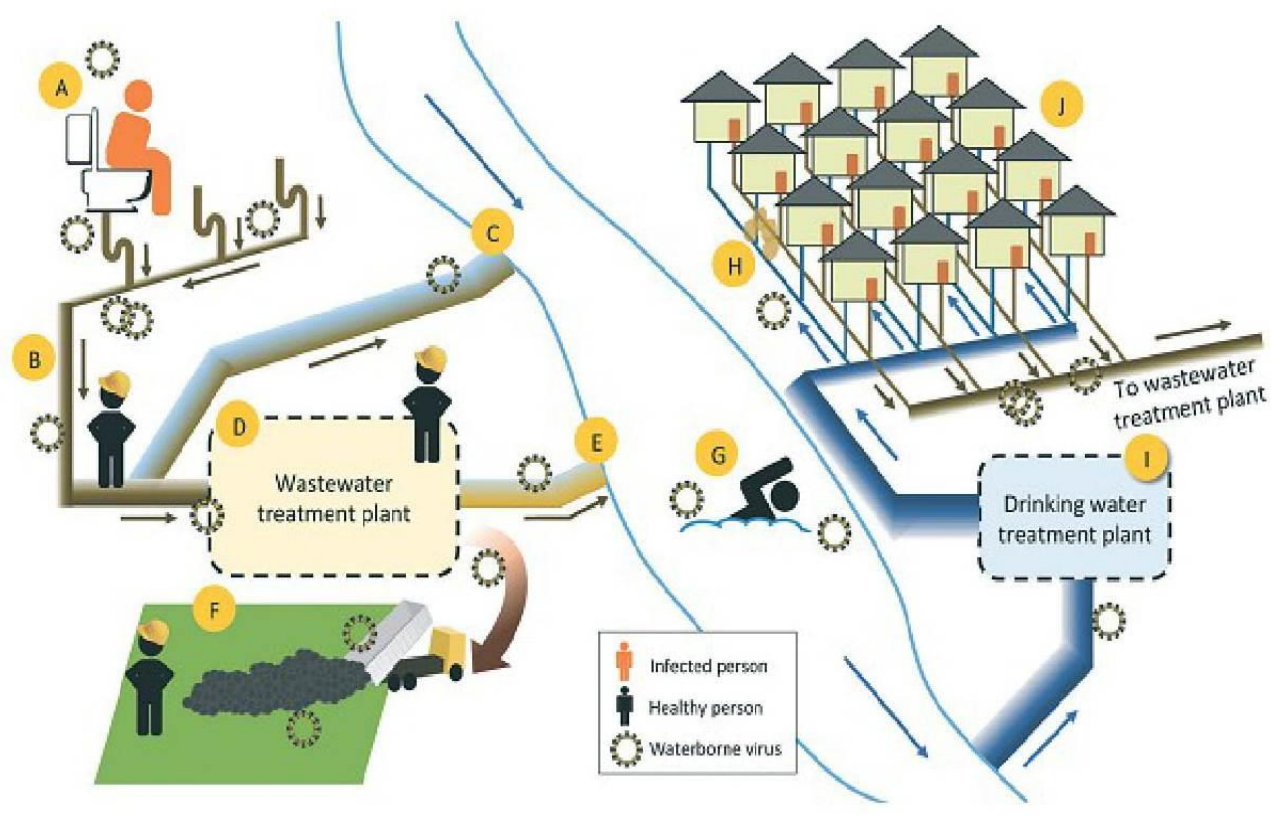

Gambar 2. Transmisi virus Korona dari tinja pasien ke sistem penyaluran air limbah, sungai, dan air bersih [22]

Keterangan:

A. Virus yang ada di dalam tinja, urin dan muntahan masuk ke sistem penyaluran air limbah. Aerosol di dalam ruang toilet banyak berisi virus.

B. Virus mengalir bersama air di riul atau sewerage menuju IPAL dan pekerja sanitasi bisa terinfeksi.

C. Ada air limbah yang bervirus langsung mengalir ke sungai.

D. Virus masuk ke IPAL sehingga pekerja bisa terinfeksi virus dari air limbah yang belum diolah dan yang sudah diolah, juga terinfeksi dari virus di dalam lumpur (sludge, biosludge, biosolid).

E. Efluen atau air limbah olahan yang masuk ke sungai masih berpotensi berisi virus.

F. Virus yang bertahan (survive) di dalam lumpur (sludge, biosludge, biosolid) yang diolah atau dibuang bisa menginfeksi pekerja dan orang lain yang bersentuhan dengan lumpur tersebut.

G. Virus bisa menginfeksi orang yang berenang atau menggunakan air sungai yang menerima efluen IPAL.

H. Pipa air limbah yang bocor bisa menginfeksi penduduk yang menggunakan air PDAM yang pipanya bocor.

I. Air baku PDAM yang berasal dari sungai bisa berisi virus karena menerima efluen IPAL atau karena Buang Air Besar Sembarang (BABS).

J. Penduduk bisa terinfeksi virus karena berasal dari air PDAM yang terinfeksi virus atau dari rembesan air limbah yang pipanya bocor dan masuk ke pipa distribusi yang juga bocor [39].

Dengan mendahulukan precautionary principle (prinsip kehati-hatian) maka dapat dikatakan bahwa ada sejumlah konsentrasi virus yang mampu hidup dan bertahan di kolam anaerobik. Juga mampu replikasi di dalam sel mikroba anaerob, termasuk archae metanogenik. Kolam oksidasi adalah kolam yang berlimpah dengan mikroba strict anaerob dan aerotolerants anaerob sehingga makin banyak virus yang bisa melakukan replikasi. Kolam ini harus mendapat perhatian khusus dari operator IPAL karena air limbah dan lumpurnya (sludge) kaya dengan virus yang berpotensi menginfeksi pekerja. Apabila sejumlah konsentrasi virus di kolam anaerobik ini mampu bertahan maka selanjutnya virus tersebut mengalir dan masuk ke kolam fakultatif. Kolam fakultatif adalah kolam yang menerima air limbah dengan tingkat polusi medium dan kecepatan pembebanan organiknya lebih kecil daripada kolam anaerobik. Kolam fakultatif juga biasa disebut wastewater lagoon (sebuah misnomer atau salah kaprah) dengan kedalaman air antara 1,2-2,5 m.

Secara alamiah kolam ini terbagi menjadi dua lapisan, yaitu lapisan anaerobik di bawah dan lapisan aerobik di atas. Di antara kedua lapisan tersebut ada lapisan fakultatif. Waktu yang dibutuhkan untuk pengolahan air limbah di kolam fakultatif ini antara 5-30 hari. Adapun endapan zat organik di kolam ini diolah oleh bakteri anaerob yang menghasilkan gas metana, karbondioksida, hidrogen sulfida, ammonia [32].

[19] menjelaskan bahwa di dalam kolam fakultatif terjadi proses utama dalam reduksi zat organik dengan kehadiran simbiosis mutualisme antara bakteri heterotrof dan algae. Bakteri heterotrof ini serupa 
dengan bakteri di unit activated sludge atau trickling filter yang bertugas mengolah pencemar organik di dalam zone aerobik menjadi produk akhir oksidasi. Di bagian atas kolam fakultatif terjadi proses aerobik sehingga kaya oksigen. Oksigen di lapisan aerobik ini berasal dari dua proses alamiah yaitu reaerasi dari atmosfer dan hasil fotosintesis algae dengan bantuan sinar matahari. Algae menggunakan nutrisi dan karbondioksida yang dihasilkan oleh bakteri aerob dan archae anerob untuk proses fotosintesis. Simbiosis mutualisme inilah air limbah diolah dalam kolam fakultatif.

Merujuk pada karakteristik kolam fakultatif tersebut maka dapat disimpulkan bahwa kondisinya mendukung untuk pertumbuhan virus Korona baru. Proses yang terjadi tidak jauh berbeda dengan proses di kolam anaerobik yaitu di bagian bawah kolam fakultatif yang kondisinya anaerob. Sedangkan bagian atas kolam bersifat aerob sehingga persistensi virus Korona baru bisa lebih mudah direduksi dan lebih mudah dinonaktifkan. Kondisi aerobik yang banyak mengandung oksigen hasil fotosintesis algae ikut memberikan peluang hidup bagi bakteri aerob sehingga berpeluang menonaktifkan virus [35]. Operator IPAL juga harus waspada karena aliran air limbah yang masuk ke dalam kolam bisa saja teraduk (mixing) secara alamiah sehingga bagian atas yang aerob bisa pindah ke bawah dan bagian bawah yang anaerob bisa pindah ke atas. Perbedaan densitas air karena perubahan temperatur atmosfer dan cuaca bisa menjadi penyebabnya.

Seperti dinyatakan oleh [37], ada potensi efluen kolam fakultatif ini mengandung banyak bakteri dan virus. Efluen ini kemudian masuk ke kolam maturasi dimana sesuai dengan namanya, di kolam ini terjadi proses pematangan (maturation) zat padat tersuspensi dan zat organik terlarut dan terjadi reduksi bakteri dan virus. Kolam maturasi ini memiliki kedalaman antara $30-45 \mathrm{~cm}$ sehingga sinar matahari dapat menembus ke semua lapisan kedalaman air. Sinar ultraviolet mampu membasmi bakteri dan virus seperti dinyatakan pada Gambar 1. Sinar ultraviolet mampu mendestruksi virus tetapi kemampuan destruksinya berkurang apabila virus berada makin dalam dari permukaan air [40]. Temperatur air di kolam maturasi juga lebih tinggi daripada di kolam fakultatif dan kolam anaerobik karena air di kolam maturasi lebih jernih, sedikit mengandung zat padat tersuspensi yang dapat menghalangi sinar matahari masuk lebih dalam. Kenaikan temperatur dapat mengurangi daya tahan virus karena terjadi denaturasi protein dan kenaikan aktivitas enzim extraselular [36] [41]. Begitu pula kolam maturasi banyak mengandung oksigen sehingga bakteri aerob berkembang pesat yang diharapkan mampu mereduksi persistensi virus [35].

Dapatkah dikatakan bahwa efluen kolam maturasi sudah bebas dari bakteri dan virus? Jawabannya, belum bisa bebas bakteri dan virus karena efluen IPAL masih mengandung virus 50-100 pfu/L [37]. Sedikit saja bakteri dan virus yang ada di kolam maturasi terbawa ke luar menuju sungai maka dapat menyebarkan virus ke masyarakat. Potensi kontak virus dengan manusia menjadi mudah karena air sungai digunakan untuk mandi, sikat gigi, mencuci beras dan sayur dan aktivitas lainnya. Apalagi air limbah yang masuk ke IPAL Bojongsoang adalah air limbah mentah tanpa klorinasi. Proses pengolahan di IPAL milik PDAM Kota Bandung ini hanya mengandalkan peran archae anaerob, bakteri fakultatif, bakteri aerob dan cahaya matahari, tidak ada preklorinasi dan postklorinasi.

Apabila dilengkapi dengan preklorinasi apakah pembasmian mikroba dan virus akan maksimum? Pembasmian tidak bisa optimal karena air limbah mentah berlimpah dengan zat padat serpihan feses. Serpihan dalam ukuran satu milimeter akan dijadikan tempat berlindung bagi bakteri dan virus sehingga sulit disentuh oleh disinfektan klor. Klor akan sulit mencapai bakteri dan virus yang berada di bagian dalam serpihan feses tersebut. Bakteri, virus, dan kista protozoa terlindungi oleh zat padat yang ada di dalam air limbah [42]. Daya tahan virus juga dipengaruhi oleh temperatur, zat organik (seperti feses), dan adanya mikroba aerob [41][43] [44].

Selain air limbah, apakah lumpur (sludge) di IPAL juga berbahaya? Sludge adalah endapan bioflok yang terdiri atas banyak jenis mikroba dan virus. Operator IPAL sebisa mungkin tidak kontak langsung dengan sludge tanpa Alat Perlindungan Diri (APD). Sludge atau biosludge di tiga jenis kolam tersebut berpotensi menyebarkan patogen ke dalam air sungai, air tanah, dan tanah yang dapat meningkatkan risiko terhadap kesehatan manusia [45]. Semua endapan sludge di dasar kolam anerobik, fakultatif dan maturasi berisiko karena cahaya matahari hanya mampu mencapai bagian permukaan air. Sinar matahari tidak mampu menembus zat padat serpihan feses yang mengadsorbsi virus apalagi kalau berada di bagian bawah permukaan air. Begitu juga pada waktu malam ketika tidak ada sinar matahari yang mengenai air limbah. Padahal air limbah yang berisi virus mengalir ke sungai siang dan malam selama 24 jam sehari.

Di negara-negara yang sistem riulnya memenuhi syarat teknis dan operasional karena diawali oleh perencanaan dan perancangan yang memenuhi kaidah hidrolika dan biokimia maka strategi pemantauan bisa menjadi mudah dan tepat. IPAL-nya juga menggunakan proses aerob seperti activated sludge dan modifikasinya sehingga lebih mampu membasmi virus. Penggunaan activated sludge memang lebih mahal dibandingkan dengan kolam oksidasi. Masih ada masalah sanitasi lainnya di Kota Bandung yaitu 
Buang Air Besar Sembarang (BABS) atau buang air besar di water closet (WC) di dalam rumah tetapi disalurkan langsung ke selokan atau sungai. Perilaku seperti ini pernah menimbulkan wabah penyakit hepatitis di India di sekitar Sungai Jumna (Yamuna). Jangan sampai pada masa depan terjadi wabah yang berawal dari air limbah oleh virus baru yang lebih persisten dan resisten terhadap zat kimia klor.

Peneliti menyimpulkan bahwa IPAL Bojongsoang milik PDAM Kota Bandung belum mampu mencegah sebaran virus. Apabila ada virus Korona baru yang masuk ke sistem riul kota dari feses pasien COVID-19 maka belum ada mekanisme pengolahan yang optimal untuk menonaktifkan virus Korona baru. Namun demikian masih ada upaya yang bisa ditempuh yaitu dengan melengkapi kolam oksidasi dengan proses klorinasi, terutama setelah kolam maturasi. Meskipun tidak maksimum dalam membasmi virus tetapi masih bisa bermanfaat daripada tidak ada sama sekali proses klorinasi. Pemakaian fasilitas APD untuk operator dan kedisiplinan operator dalam memakai APD juga perlu ditingkatkan. Upaya pencegahan tersebut perlu dilaksanakan untuk mencegah virus-virus baru lainnya pada masa depan yang dapat menginfeksi penduduk yang memanfaatkan air sungai.

\subsection{New Normal}

Pada masa new normal diperlukan sikap dan perilaku baru yang berbeda dengan masa normal sebelumnya. Secara mikrobiologi, new normal adalah kondisi setelah wabah (pascapandemi) yang sudah melewati fase decline (decrease). Di dalam jurnal Annu. Rev. Microbiology, 1949: 3: 371-394 Jacques Monod menjelaskan tentang pola pertumbuhan bakteri. Kurva pertumbuhan mikroba ini bisa dijadikan analogi untuk persebaran wabah COVID-19. Sekali lagi, kurva ini adalah analogi pertumbuhan dan pengurangan jumlah penderita COVID-19.

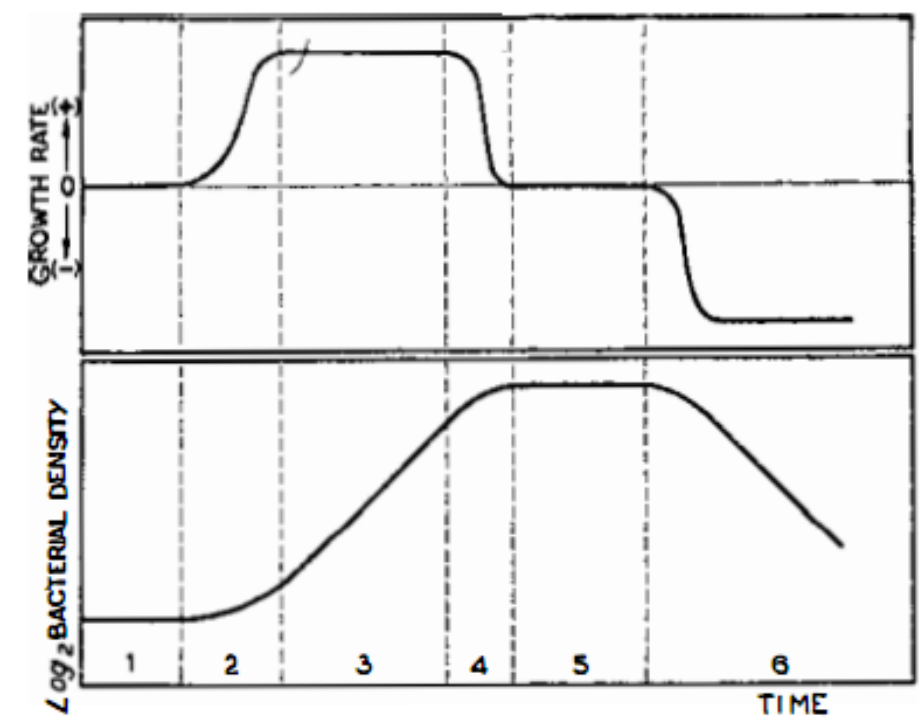

Gambar 3. Fase pertumbuhan mikroba [22]

Keterangan:

1. Lag phase: growth rate null, adalah fase adaptasi;

2. Acceleration phase: fase percepatan laju pertumbuhan;

3. Exponential phase: fase laju tinggi, growth rate constant

4. Retardation phase: fase perlambatan pertumbuhan, growth rate decreases

5. Stationary phase: fase stabil, growth rate null

6. Phase of decline: fase penurunan, growth rate negative

[46]

Kurva dimulai dari fase lag, yaitu fase adaptasi dengan laju pertumbuhan nol. Kemudian fase akselerasi, yaitu laju pertumbuhan mulai meningkat. Berikutnya adalah fase eksponensial yaitu laju pertumbuhan tinggi dan lajunya konstan tinggi selama beberapa waktu sampai memasuki fase perlambatan (retardation) ketika laju pertumbuhan mulai menurun. Selanjutnya adalah fase stationary, yaitu fase pertumbuhan nol sehingga jumlah penderita relatif konstan. Terakhir adalah fase decline atau decrease, yaitu laju pertumbuhan negatif yang artinya jumlah penderita berkurang seiring dengan pergantian hari. Pengurangan ini membutuhkan waktu relatif lama sampai tercapai kondisi seperti semula pada waktu yang baru. Pada titik inilah bisa disebut fase awal yang berada di depan gerbang new normal. 
Masuk ke fase new normal secara makna harfiah adalah setelah ditemukan vaksin yang bisa digunakan di seluruh dunia, diproduksi masal, dan murah harganya bagi mayoritas penduduk dunia.

New normal adalah keadaan atau kondisi yang diharapkan normal dalam kehidupan sosial masyarakat tetapi konsisten melaksanakan protokol kesehatan dalam beberapa tahun ke depan. Bisa disebut sebagai tatanan dunia baru karena terjadi di seluruh dunia. Pada masa new normal ini maka peran PDAM menjadi signifikan dalam menyediakan air bersih untuk cuci tangan tanpa sabun karena sudah berisi klor, untuk membersihkan lantai, meja, kursi tempat ibadah dan semua benda lainnya. PDAM juga hendaklah berupaya mengelola IPAL yang mampu membasmi bakteri dan virus Korona baru serta senantiasa menerapkan protokol kesehatan untuk operator IPAL.

\section{Kesimpulan}

Semua artikel yang membahas virus Korona penyebab SARS dan MERS menegaskan bahwa virus Korona bisa menyebar lewat percikan atau muncratan liur (droplets) yang mengenai orang lain dan bertahan aktif di benda-benda termasuk air minum. Karakteristik demikian juga berlaku untuk novel Corona virus penyebab COVID-19. Semua virus bisa dinonaktifkan dengan zat kimia seperti sabun, deterjen dan senyawa klor. Air PDAM diolah dengan proses klorinasi dan memiliki sisa klor bebas sehingga efektif membasmi bakteri dan virus. Klorinasi efektif menonaktifkan virus Korona baru dan jenis virus lainnya sehingga air PDAM layak digunakan untuk mencuci benda-benda di fasilitas umum yang diduga berisi virus. Dosis klor yang bisa diterapkan adalah $0,2-40 \mathrm{mg} / \mathrm{l}$ dengan sisa klor bebas $0,2-$ $0,5 \mathrm{mg} / \mathrm{l}$. Air sumur yang digunakan untuk fasilitas umum sebaiknya diolah dengan kaporit tablet pada masa wabah COVID-19 dan pada masa normal baru.

Jejak genetis virus Korona baru ditemukan di dalam sampel air limbah di Belanda. Virus korona baru masih satu famili dengan virus penyebab SARS dan MERS. Virus SARS sudah menyebar di dalam air limbah yang mengalir di dalam pipa-pipa gedung dan menginfeksi banyak orang yang menggunakan fasilitas alat plumbing tersebut. Jejak genetis virus SARS juga ditemukan di dalam air limbah mentah dan di dalam air limbah yang sudah diolah dengan disinfektan. Instalasi pengolahan air limbah kolam oksidasi tidak optimal dalam membasmi bakteri dan virus. Kemampuan archae anaerob lemah dalam mereduksi persistensi virus apabila dibandingkan dengan kemampuan bakteri aerob sehingga kolam yang optimal dalam membasmi bakteri dan virus adalah kolam maturasi. Sinar ultraviolet dari matahari juga mampu masuk lebih dalam ke dasar kolam maturasi. Tetapi pada waktu malam ketika tidak ada sinar matahari maka kemampuannya berkurang.

Kolam oksidasi di IPAL Bojongsoang milik PDAM Kota Bandung tidak dilengkapi dengan proses klorinasi sehingga harus diwaspadai oleh masyarakat pengguna air Sungai Citarum sebagai badan air yang menerima efluen IPAL Bojongsoang. Prinsip kehati-hatian (precautionary principle) diperlukan agar terhindar dari bahaya laten virus baru pada masa new normal atau tatanan baru kehidupan pascapandemi. Peran PDAM sebagai penyedia air bersih yang berisi disinfektan klor menjadi makin penting pada masa normal baru.

\section{Daftar Pustaka}

[1] Schoeman dan Fielding. Coronavirus envelope protein: current Knowledge, Virology Journal, 16:69. 2019

[2] Manocha, S., Walley, K.R., Russell, J.A. Severe acute respiratory distress syndrome (SARS): A critical care perspective. Critical Care Medicine, 31, 2684-2692. 2003

[3] Guan, Y., Zheng, B. J., He, Y. Q., Liu, X. L., Zhuang, Z. X., Cheung, C. L. Isolation and characterization of viruses related to the SARS Coronavirus from animals in Southern China. Science, 302, 276-279. 2003

[4] Lau, S. K. P., Woo, P. C. Y., Li, K. S. M., Huang, Y., Tsoi, H. W., Wong, B. H. L. Severe acute respiratory syndrome coronavirus-like virus in Chinese horseshoe bats. Proceedings of the National Academy of Sciences of the United States of America, 102(39), 14040-14045. 2005

[5] Wang, L. F., Shi, Z., Zhang, S., Field, H., Daszak, P., \& Eaton, B. T. 2006. Review of bats and SARS. Emerging Infectious Diseases, 12(12), 1834-1840.

[6] Belshe, R. B. 1984. Textbook of human virology. Littleton: PSG Publishing Co, Inc.

[9] Bosch, A., Rosa M. Pintó, and F. Xavier Abad. Survival and Transport of Enteric Viruses in the Environment. (www.ub.edu). 2006

[10] Bosch , A., Human enteric viruses in the water environment: a mini review International Microbiology, Vol. 1: 191-196, (C) Springer-Verlag Ibérica. 1998 
[11] Treado, S., M. Kedzierski, S. Watson, K. Cole. Contamination and Decontamination of Building Plumbing Systems. National Institute of Standards and Technology Gaithersburg, AIChE Annual Conference. 2006

[12] WHO. Guidelines for drinking water quality, 4th ed. World Health Org. Geneva, pp 1-541. 2011

[13] Doremalen, N. V., Bushmaker, Morris. The New England Journal of Medicine edisi 17 Maret 2020, a letter to the Editors of NEJM.org. 2020

[14] Tchobanoglous, G., Metcalf \& Eddy. Wastewater Engineering: Treatment, Disposal, Reuse, McGraw-Hill. 2003

[15] Reynold, T., Richard, P, A. Unit Operation and Processes in Environment Engineering Second Edition. PWS Publishing Company. 1996

[16] Fair G. M., J. C. Geyer, D. A. Okun. Water and Wastewater Engineering. Wiley, Vol.2. 1968

[17] Developments in Water Science. Waste Water Disinfection. Wastewater and Sludge Chlorination for Various Purposes, Chapter 11, Vol. 23, pp. 438-456. 1985

[18] Snoeyink, V dan Jenkins, D. Water Chemistry, John Wiley \& Sons, New York. 1980

[19] Droste. Theory and Practice of Water and Wastewater Treatment. John Wiley, USA. 1997

[20] Cahyana, G. H. PDAM Bangkrut, Awas Perang Air, Sahara Golden Press Indonesia. 2004

[21] Clark, R. M., E. J. Read, J. C. Hoff. 1989. Analysis of Inactivation of Giardia Lamblia by Chlorine. Journal of Environmental Engineering, ASCE, 115: 80-90

[22] USEPA. Water Treatment Manual Disinfection. 2011

[23] Lawler D. F. dan P. C. Singer. Analyzing Disinfection Kinetics and Reactor Design: a Conceptual Approach versus the SWTR, J. American Water Works Association, 85, 11, pp. 67-76. 1993

[24] Pontius, F. W. Configuration, operations of system affect C x T value, Opflow 19(8): 7-8. 1993

[25] Lin, D. S. Water and Wastewater Calculation Manual, McGraw-Hill, USA. pp. 447-450. 2001

[26] Sawyer, C. N., McCarty P. L. Chemistry for Environmental Engineering, McGraw-Hill Book, Singapore. 1989

[27] Wang XW, Li J, Guo T, Zhen B, Kong Q, Yi B, Li Z, Song N, Jin M, Xiao W, Zhu X, Gu C, Yin J, Wei W, Yao W, Liu C, Li J, Ou G, Wang M, Fang T, Wang G, Qiu Y, Wu H, Chao F, Li J. Concentration and detection of SARS coronavirus in sewage from Xiao Tang Shan Hospital and the 309th Hospital of the Chinese People's Liberation Army. Water Sci Technol. 52(8):213-21. 2005

[28] Murphy, H dan B. Soule. Water Quality \& Health Council. (Akses 20 April 2020)

[29] Peiris, J. S. M., Chu, C. M., Cheng, V. C. C., Chan, K. S., Hung, I. F. N., Poon, L. L. M. Clinical progression and viral load in a community outbreak of coronavirus-associated SARS pneumonia: A prospective study. The Lancet, 361, 1767-1772. 2003

[30] Leung, W. K., To, K. F., Chan, P. K. S., Chan, H. L. Y., Wu, A. K. L., Lee, N. Enteric involvement of severe acute respiratory syndrome-associated coronavirus infection. Gastro-enterology, 125, 1011-1017. 2003

[31] Chan, K. H., Poon, L. M., Cheng, V. C. C., Guan, Y., Hung, I. F. N., Kong, J., Detection of SARS coronavirus in patients with suspected SARS. Emerging Infectious Diseases, 10, 294-299. 2004

[32] Horan, N. J. Biological Wastewater Treatment Systems, John Wiley \& Sons. 1990

[33] Speece. R. E. “Anaerobic Biotechnology for Industrial Wastewaters”. Archae Press. 1996

[34] Gottschalk, G. Bacterial Metabolism, Springer-Verlag, 2 ${ }^{\text {nd }}$. Ed., New York. 1986

[35] Hurst, C. J. Influence of aerobic microorganisms upon virus survival in soil. Can. J. Microbiol. 34: 696-699. 1987

[36] Hurst, C. J., Gerba, C. P., and Cech, I. Effects of environmental variables and soil characteristics on virus survival in soil. Appl. Environ. Microbiol. 40: 1067-1079. 1980

[37] Rao, V. C., Melnick, J. L. Environmental virology, in: Aspects of Microbiology 13 (J.A. Cole, C. J. Knowles, and D. Schlessinger, eds.), American Society for Microbiology, Washington, DC. 1986

[38] Yinyin, Y, Ellenberg, R. M., Graham, K. E., Krista R. Survivability, Partitioning, and Recovery of Enveloped Viruses in Untreated Municipal Wastewater, Environ. Sci. Technol., 50, 5077-5085. 2016

[39] Wigginton K. R, Y. Ye and R. M. Ellenberg. Emerging investigators series: the source and fate of pandemic viruses in the urban water cycle, Environ. Sci.: Water Res. Technol, 1, 735. 2015

[40] Bitton, G. Introduction to Environmental Virology, John Wiley \& Sons, New York. 1980

[41] John, D. E., Rose, J. B. Review of factors affecting microbial survival in groundwater. Environmental Science \& Technology, 39 (19), 7345-7356. 2005

[42] Chen Y. S. R., O. J. Sproul, A. J. Rubin. Inactivation of Naegleria gruberi cysts by chlorine dioxide. Water Research, 19 (6): 783-789. 1985 
[43] Melnick, J. L., \& Gerba, C. P. The ecology of enteric viruses in natural waters. Critical Reviews in Environmental Control, 10, 65-93. 1980

[44] Sobsey, M. D., \& Meschke, J. S. Virus survival in the environment with special attention to survival in sewage droplets and other environmental media of fecal or respiratory origin. Report for the World Health Organization, Geneva, Switzerland, p. 70. 2003

[45] Zhao, Q., Y. Liu. Is anaerobic digestion a reliable barrier for deactivation of pathogens in biosludge? Sci. Total Environ. 893-902. 2019

[46] Monod, J, Annu. Rev. Microbiol., 3: 371-394, Pasteur Institute, Paris, France, diunduh dari www.annualreviews.org. 1949 